\title{
Surveillance of the Safety of Oral Poliomyelitis Vaccine in England and Wales 1962-4
}

\author{
D. L. MILLER,* M.A., M.D., D.P.H. ; N. S. GALBRAITH, $\dagger$ M.B., B.S., D.P.H.
}

Brit. med. F., 1965, 2, 504-509

When, in 1956, inactivated poliomyelitis (Salk) vaccine became available for routine immunization in England and Wales the Ministry of Health set up a scheme of poliomyelitis surveillance. The objects were to provide a means of rapid detection of possible outbreaks of vaccine-induced poliomyelitis, such as occurred in the United States owing to the presence of incompletely inactivated virus in a batch of vaccine (Nathanson and Langmuir, 1963), and to observe the efficacy of the vaccine. The results were reported by Geffen and Spicer (1960), Geffen (1960), and Roden (1964), and though a number of vaccineassociated cases occurred they concluded that the vaccine was both safe and effective.

After live attenuated (Sabin) vaccine was introduced in 1962 the surveillance scheme was reorganized by the Ministry of Health and the Public Health Laboratory Service with the new aim of meeting the theoretical objection that disease might be caused in a very small proportion of persons receiving the vaccine, or their contacts, owing to the virus regaining some of its neurovirulence on passage through the human alimentary tract, a risk which would be detectable only when very large numbers of persons had been immunized. The scheme depended on inquiry into notified cases of poliomyelitis, and also on spec:al studies of notified encephalitis and cases in which poliovirus isolation was reported. In assessing the safety of oral vaccine the following circumstances were regarded as significant indicators of possible vaccine-induced disease: (1) undue frequency of poliomyelitis in recently vaccinated persons ; (2) an aggregation of dates of onset of illness within a month of vaccination, particularly between 5 and 28 days; (3) undue frequency of cases associated with a single batch, or small number of batches of vaccine; and (4) an age, sex, seasonal, and geographical distribution of vaccine-associated cases inconsistent with the distribution of other cases of poliomyelitis.

Galbraith (1963) analysed the results for 1962 and concluded there was no evidence of vaccine-induced disease at that time, although studies in the United States (Terry, 1962) suggested that a few cases of paralytic poliomyelitis in vaccinated persons might have been caused by the vaccine and that the risk, though small, was greatest after administration of type 3 monotypic vaccine to adults. These findings have been endorsed by a more recent review of cases in the United States (Special Advisory Committee, 1964). The present paper summarizes the results of surveillance in England and Wales for the three years 1962-4, during which oral vaccine has been used for routine immunization.

\section{Methods}

Medical officers of health completed a special immediate report form for every notified case of poliomyelitis and sent it as soon as possible to the Epidemiological Research Laboratory of the Public Health Laboratory Service. Recorded on this form were the patient's name, address, sex, date of birth, date of onset of symptoms, whether or not paralysis was present, the

\footnotetext{
* Epidemiological Research Laboratory, Central Public Health Laboratory, Colindale, London.

t Health Department, Londun Borough of Newham.
}

patient's poliomyelitis vaccination history, and details of household members who had received oral vaccine within 28 dayslater extended to 60 days-before onset of the patient's symptoms. Reports were checked weekly against notifications published by the Registrar-General to ensure that a form had been received for eyery notified case.

A second form was sent for completion by the doctor in clinical charge of the case giving details of the patient's illness, the presence and extent of paralysis, laboratory findings, and the final diagnosis. Subsequently inquiry was made about residual paralysis in vaccine-associated paralytic cases.

Apart from notified cases of poliomyelitis, information was collected from a variety of sources about other cases of neurological disease associated with oral vaccination of the patient or his household contacts. Between April 1963 and April 1964 an inquiry was made into all notified cases of encephalitis and reported deaths from encephalitis to find out whether they were associated with oral poliomyelitis vaccination. In 1963 and 1964 details were obtained of all patients with neurological symptoms from whom poliovirus isolations were reported by public health and hospital laboratories. A few cases of vaccineassociated disease were reported to the laboratory by clinicians.

\section{Results}

During 1962-4 428 cases of poliomyelitis were reported to the Epidemiological Research Laboratory (Table I). In 97 of these the diagnosis was later revised by the physician on clinical grounds. There were therefore 331 confirmed cases, of which 278 were paralytic and 53 non-paralytic. Thirteen cases, eight

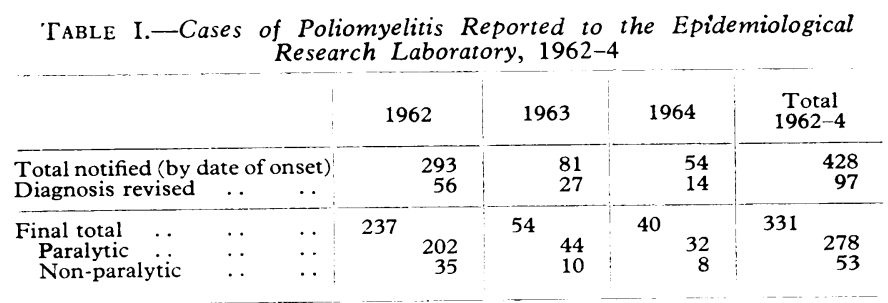

of them paralytic, were reported to the laboratory but not notified to the Registrar-General. Because of the difficulty in diagnosing non-paralytic poliomyelitis, especially in the absence of epidemics, such cases have been omitted from most of the analyses. Four cases infected overseas have also been excluded.

\section{Doses of Oral Vaccine Administered}

It is estimated from the number of doses of vaccine issued by the Ministry of Health that between February 1962, when oral vaccine was introduced, and the end of 1964 about 18 million doses were administered in England and Wales. By the end of 1964 records were received for 2,536,000 persons who had completed primary immunization with three doses of oral vaccine. Most were children: $1,458,445$ aged up to 4 years, and 596,088 aged 4 to 21 years. Only 481,467 adults were given 
three doses of oral vaccine without previous Salk vaccination. A further 1,650,703 persons had received one or two doses of oral vaccine to complete primary immunization after previous Salk vaccination and 1,693,257 persons a reinforcing dose after completion of primary immunization. The estimated number of doses of vaccine used is not fully accounted for by these figures, probably mainly owing to delay in the receipt of records.

\section{Vaccine-associated Cases of Paralytic Poliomyelitis}

There were 20 patients with paralytic poliomyelitis who had received oral poliomyelitis vaccine within 28 days before onset of symptoms (Table II), and another 11 whose household contact had been vaccinated within this period (Table III).

Poliomyelitis Vaccination Histories.-It is not possible to calculate the incidence of poliomyelitis in vaccinated and unvaccinated persons, because records of the ages of vaccinated persons are incomplete. - Furthermore, the practice of vaccinating persons in districts where a case of poliomyelitis occurred would make a comparison of incidence by vaccination history difficult to evaluate. There was, however, no suggestion of an unduly high incidence in recently vaccinated persons. Seventyone per cent. of all cases of paralytic poliomyelitis had not received any Salk or Sabin vaccine, and the proportion was similar for vaccine-associated and other cases. Fewer vaccineassociated cases had received three or more doses of vaccine, probably because they were mostly young children undergoing primary immunization.
Time Interval Between Vaccination and Onset.-The onset of illness in seven of the 20 cases in which the patient was vaccinated was within five days after vaccination, before the vaccine could take effect or cause disease; six of the seven were in Monmouthshire, where a vaccination campaign took place to control an outbreak of type 1 poliomyelitis (Fig. 1a). Of the remaining 13 cases, seven made complete or near complete

(a) PATIENT VACCINATED WITHIN 28 DAYS

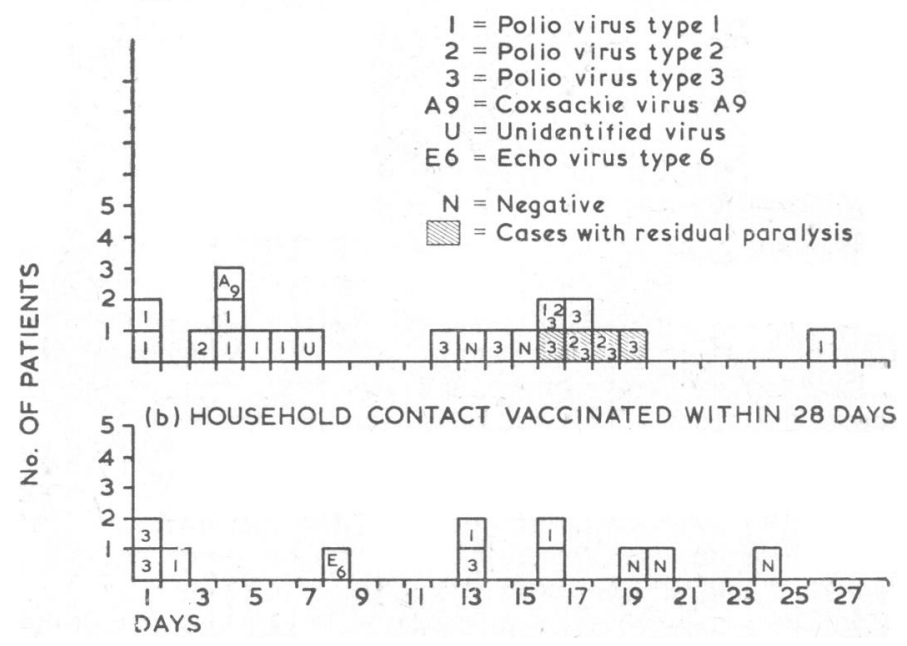

FIg. 1.-Time intervals between oral vaccination and onset of symptoms. Cases of paralytic poliomyelitis. England and Wales, 1962-4.

Table II.-Patients with Paralytic Poliomyelitis Receiving Oral Vaccine within 28 Days before Onset of Symptoms

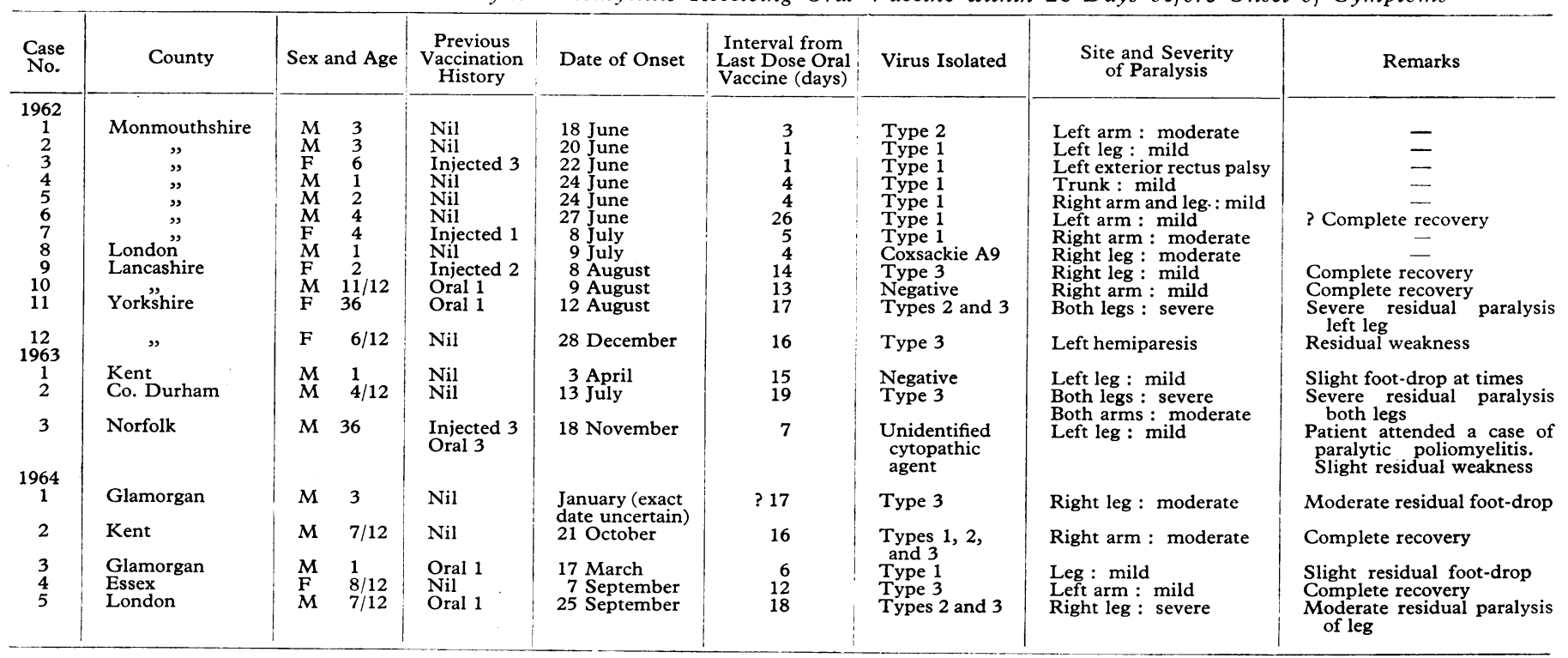

TABle III.-Patients with Paralytic Poliomyelitis whose Household Contact Received Oral Vaccine within 28 Days before Onset of Symptoms

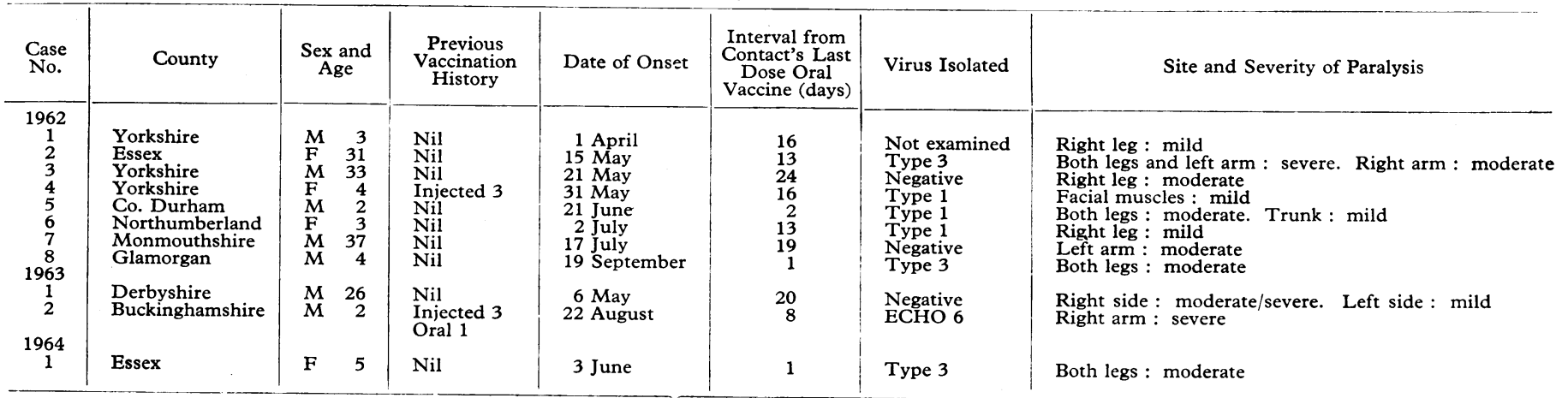


recoveries, and in two the diagnosis was doubtful. In only four cases, all occurring from 16 to 19 days after vaccination, was there definite residual paralysis. The dates of onset of illness in the patients whose household contact was vaccinated were distributed evenly over the 28 days after vaccination (Fig. 1b). Extension of this inquiry to include cases occurring up to 60 days after vaccination (Galbraith, 1963) showed a similar distribution of cases with onsets between 29 and 60 days after vaccination.

Vaccine Batches.-The vaccine given to the vaccine-associated cases was from at least 16 different batches prepared by three manufacturers. The number of vaccine-associated cases reported in each year followed the falling incidence of poliomyelitis in 1962-4 rather than the number of doses of oral vaccine given.

Sex and Age Distribution.-Of the 278 paralytic cases notified 166 were males and 112 females; 21 of the vaccineassociated cases were males and 10 females. The age distribution of paralytic cases is shown in Table IV. A higher proportion of vaccine-associated cases than of other cases were children aged $0-4$ years. This excess of vaccine-associated cases in young children is probably in proportion to the much greater use of vaccine in children than in adults: $57 \%$ of persons completing a primary course of immunization with three doses of oral vaccine were aged under 4 years and only $19 \%$ were adults, though a higher proportion of those receiving reinforcing doses of oral vaccine were probably older children and adults. In the United States vaccine-associated cases formed a higher proportion of all cases in adults than in children (Henderson et al., 1964), but in this study the reverse was true: $13 \%$ of those under the age of 15 years were vaccine-associated compared with $7 \%$ of those aged 15 and over.

Table IV.-Age Distribution of Cases of Paralytic Poliomyelitis, 1962-4

\begin{tabular}{|c|c|c|c|c|c|c|c|c|}
\hline \multicolumn{3}{|c|}{ Age (Years) } & \multicolumn{2}{|c|}{$\begin{array}{c}\text { Vaccine- } \\
\text { associated }\end{array}$} & \multicolumn{2}{|c|}{ Other } & \multicolumn{2}{|c|}{ All Cases } \\
\hline $\begin{array}{cc}0-4 & \cdots \\
5-9 & \cdots \\
10-14 & \ldots \\
15-24 & \therefore \\
25 & \text { and over }\end{array}$ & $\begin{array}{l}. \\
\cdots \\
\cdots \\
\cdots\end{array}$ & \begin{tabular}{l|l|}
$\ldots$ & \\
$\cdots$ & \\
$\cdots$ & \\
$\cdots$ &
\end{tabular} & $\begin{array}{r}23 \\
2 \\
0 \\
0 \\
6\end{array}$ & $\begin{array}{c}(74 \%) \\
(7 \%) \\
\overline{(19 \%)}\end{array}$ & $\begin{array}{r}106 \\
48 \\
14 \\
23 \\
54\end{array}$ & $\begin{array}{r}\left(43^{\circ}\right) \\
(20 \%) \\
(6 \% \%) \\
(9 \%) \\
\left(22^{\circ} \%\right)\end{array}$ & $\begin{array}{r}129 \\
50 \\
14 \\
23 \\
60\end{array}$ & $\begin{array}{l}\left(47^{\circ}\right) \\
\left(11^{\circ}\right) \\
(5 \%) \\
(8 \%,) \\
\left(22^{\circ} 0_{0}^{\circ}\right)\end{array}$ \\
\hline Total .. & .. & .. & 31 & $(100 \%)$ & $245^{*}$ & $(100 \%)$ & $276^{*}$ & $\left(100^{\circ}\right)$ \\
\hline
\end{tabular}

* Excluding two cases in which age was not stated.

Seasonal and Geographical Distribution.-Since 1962 the former summer peak in incidence of poliomyelitis has almost disappeared and no outbreaks or geographically associated cases of paralytic poliomyelitis have been reported. Galbraith (1963) showed that both the seasonal and geographical distributions of vaccine-associated paralytic cases in 1962 were similar to those of other cases. There was no evidence that the number of vaccine-associated cases was related to the number of doses of vaccine issued in local areas. The few vaccine-associated cases in 1963 and 1964 appear to have been randomly distributed in time and place.

Virus-isolation Results.-Type 1 and type 3 polioviruses were isolated from vaccine-associated cases with equal frequency (Table V). But 6 of the 11 type 1 strains were isolated in the Monmouthshire outbreak due to type 1 virus, and in sporadic cases type 3 virus was most often isolated. In three other sporadic cases viruses other than poliovirus were isolated. The frequency of polio-virus isolation from other cases of paralytic poliomyelitis was similar in 1963 and 1964 but differed from the results obtained in 1962. Although the proportion of cases which were examined for virus was similar in each of the three years, in 1962 more than two-thirds of the specimens yielded poliovirus, compared with less than one-third in 1963-4. Moreover, in 1962 nearly all strains isolated were type 1 virus, but in 1963-4 types 2 and 3 outnumbered type 1 . There was little change in the frequency of isolation of viruses other than poliovirus, and most cases in 1963-4 yielded no virus at all. There are no grounds for supposing that this change in isolation rate was due to technical reasons. The isolation rate of poliovirus from cases of paralytic poliomyelitis was greater in children than in adults, and greater in patients who had not been vaccinated against poliomyelitis than in those who had (Table VI). But the fall in isolation rate since 1962 was proportionately similar in all age-groups and in both vaccinated and unvaccinated persons.

TABle V.-Virus Isolation Results in Cases of Paralytic Poliomyelitis,

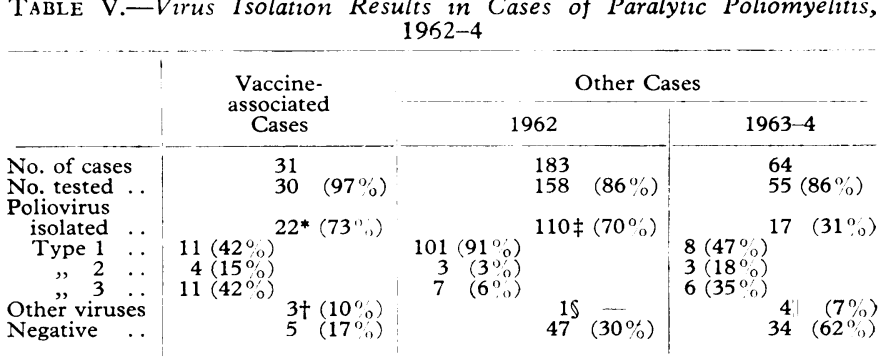

* Types 2 and 3 in two cases. Types 1,2 , and 3 in one case.

† Types 1 and 3 in one case.

Coxsackie B2 in two cases. Coxsackie A9 and ECHO 6 in one case each.

TABLE VI.-Virus Isolation Results in Relation to Age and Vaccination TABLE VI.-Virus Isolation Results in Relation to Age and Vace
History in Cases of Paralytic Poliomyelitis, 1962-4

\begin{tabular}{|c|c|c|c|c|c|c|c|}
\hline \multirow{2}{*}{\multicolumn{2}{|c|}{ Age (years) }} & \multicolumn{3}{|c|}{ Not Vaccinated } & \multicolumn{3}{|c|}{$\begin{array}{c}\text { Vaccinated } \\
\text { (One or More Doses) }\end{array}$} \\
\hline & & Total & Examined & $\begin{array}{l}\text { Poliovirus } \\
\text { Isolated }\end{array}$ & Total & Examined & $\begin{array}{l}\text { Poliovirus } \\
\text { Isolated }\end{array}$ \\
\hline $\begin{array}{cc}0-4 & \ldots \\
5-24 & \ldots \\
25 & \text { and over }\end{array}$ & $\begin{array}{l}\cdots \\
\cdots\end{array}$ & $\begin{array}{l}78 \\
48 \\
47\end{array}$ & $\begin{array}{l}69 \\
45 \\
35\end{array}$ & $\begin{array}{l}56(81 \%) \\
30(67 \%) \\
19(54 \%)\end{array}$ & $\begin{array}{r}28 \\
35 \\
8\end{array}$ & $\begin{array}{r}25 \\
28 \\
8\end{array}$ & $\begin{array}{r}8(32 \%) \\
10(36 \%) \\
2(25 \%)\end{array}$ \\
\hline Total & $\ldots$ & 173 & 149 & $105(70 \%)$ & 71 & 61 & $20(33 \%)$ \\
\hline
\end{tabular}

All vaccine-associated cases, two cases in which the age was not recorded, and one case in which the vaccine history was uncertain have been excluded from this table.

\section{Other Vaccine-associated Neurological Disease}

Details of 18 cases of neurological disease not diagnosed as paralytic poliomyelitis, but associated with the administration of oral vaccine to the patient within 28 days of onset of symptoms, are given in table VII, and their distribution in time in relation to the date of vaccination is shown in Fig. 2. Another 12 patients whose household contact had received vaccine within 60 days are recorded in Table VIII.

\section{PATIENT VACCINATED WITHIN 28 DAYS}

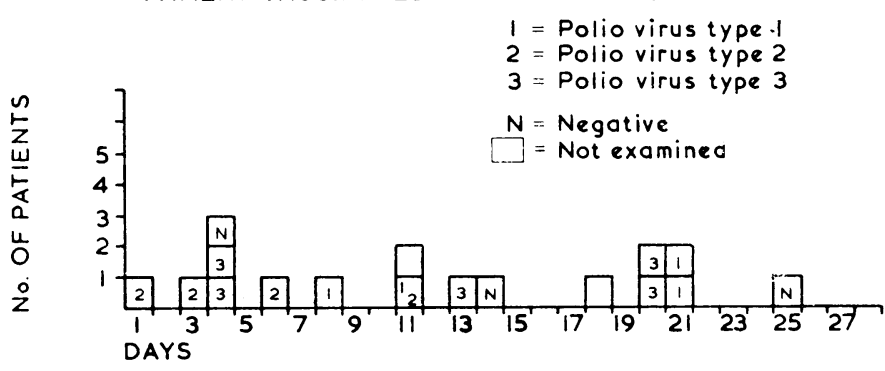

FIG. 2.-Time intervals between oral vaccination and onset of symptoms. FIG. 2.- Time intervals between oral vaccination and onset of symptoms. England and Wales, 1962-4.

Four of the 18 cases were diagnosed as non-paralytic poliomyelitis (one in 1962, one in 1963, and two in 1964). In 1962 three vaccine-associated cases of encephalitis, two of which were fatal, were brought to notice. The encephalitis survey, carried out from April 1963 to April 1964, revealed eight vaccineassociated cases of acute infective encephalitis, three of which were fatal, and the inquiry made into patients from whom the isolation of poliovirus was reported disclosed 10 cases with neurological symptoms not thought to be paralytic poliomyelitis. Eight other cases of vaccine-associated neurological disease came 
to the notice of the Epidemiological Research Laboratory in a variety of ways ; most of them were cases regarded at first as poliomyelitis but in which the diagnosis was later revised.

\section{Cases with Final Diagnoses other than Poliomyelitis}

The diagnosis was revised in 106 cases originally reported as poliomyelitis. In nine cases the reason for change of diagnosis was failure to isolate poliovirus, but it was decided to accept the revision only when made on clinical grounds, and these nine were therefore included as paralytic poliomyelitis. The revised diagnoses in 58 of the remaining 97 cases were diseases of the nervous system and in 39 were diseases of other systems.

Eleven $(11 \%)$ of the 97 cases were vaccine-associated cases, compared with $31(11 \%)$ of the 278 cases of confirmed paralytic poliomyelitis. Three of the vaccine-associated cases were diseases of the nervous system, details of which are included in Tables VII and VIII.

\section{Discussion}

Since the introduction of inactivated poliomyelitis (Salk) vaccine in 1956 the incidence of the disease in England and Wales has declined dramatically (Fig. 3). This remarkable change is probably attributable to the use of Salk and, since 1962, live attenuated (Sabin) vaccines. Doubts have been raised, however, concerning the complete safety of oral vaccine, and a Special Advisory Committee to the United States Surgeon General (1964) stated its view that at least some vaccineassociated cases were caused by the vaccine, although it was not possible to prove this in individual cases. The results presented in this report of poliomyelitis surveillance in England and Wales during the three years $1962-4$ since oral vaccine was introduced show that the risk, if any, of the vaccine causing serious disease was extremely small. This small questionable risk has to be

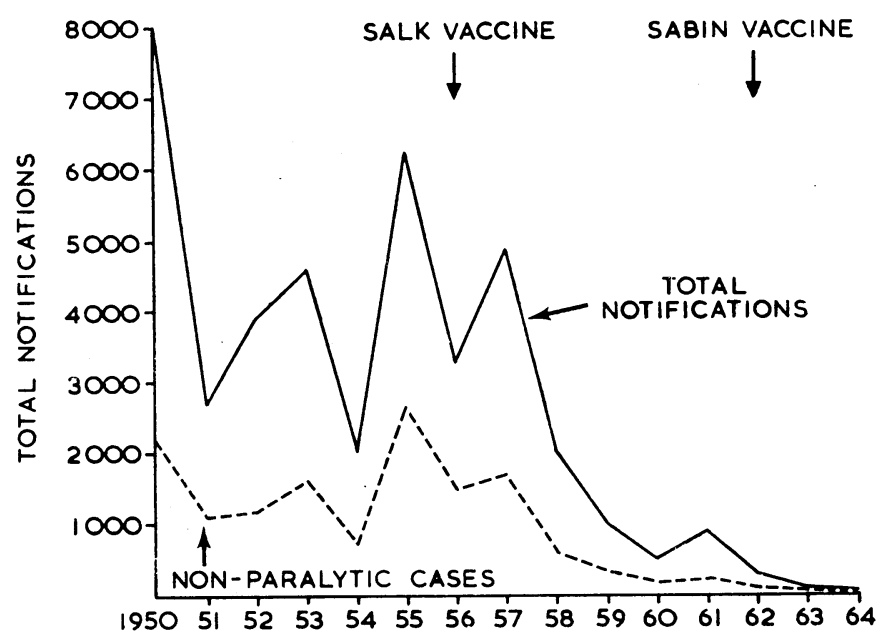

FIG. 3.-Poliomyelitis notifications. England and Wales, 1950-64.

TABle VII.-Patients with Neurological Diseases other than Paralytic Poliomyelitis Who Received Oral Vaccine within 28 Days before Onset of Symptoms

\begin{tabular}{|c|c|c|c|c|c|c|c|c|}
\hline $\begin{array}{l}\text { Case } \\
\text { No. }\end{array}$ & Sex a & nd Age & $\begin{array}{l}\text { Previous } \\
\text { Vaccination } \\
\text { History }\end{array}$ & Date of Onset & $\begin{array}{l}\text { Intervals from } \\
\text { Last Dose Oral } \\
\text { Vaccine (days) }\end{array}$ & Virus Isolated & Clinical Diagnosis & Remarks \\
\hline $\begin{array}{c}1962 \\
1\end{array}$ & & 48 & Nil & 6 July & 14 & Negative & Polyneuritis & $\begin{array}{l}\text { Severe respiratory paralysis necessi- } \\
\text { tating artificial respiration. Para- } \\
\text { lysis both arms with little recovery }\end{array}$ \\
\hline $\begin{array}{l}2 \\
3\end{array}$ & $\begin{array}{l}\mathbf{M} \\
\mathbf{M}\end{array}$ & $\begin{array}{l}7 \\
8\end{array}$ & $\begin{array}{l}\text { Injected } 3 \\
\text { Injected } 3\end{array}$ & $\begin{array}{l}1 \text { August } \\
4 \text { December }\end{array}$ & $\begin{array}{r}3 \\
25\end{array}$ & $\begin{array}{l}\text { Type } 2 \\
\text { Negative }\end{array}$ & $\begin{array}{l}\text { Non-paralytic poliomyelitis } \\
\text { Encephalitis }\end{array}$ & $\begin{array}{l}\text { Notified case } \\
\text { Unconscious } 14 \text { days. Residual } \\
\text { speech difficulty, right external } \\
\text { rectus palsy, and weakness right } \\
\text { arm }\end{array}$ \\
\hline $\begin{array}{c}1963 \\
1 \\
2 \\
3\end{array}$ & $\begin{array}{l}M \\
\mathbf{M}\end{array}$ & $\begin{array}{l}11 \\
5 \\
8 / 12\end{array}$ & $\begin{array}{l}\text { Injected } 4 \\
\text { Injected } 3 \\
\text { Nil }\end{array}$ & $\begin{array}{l}19 \text { May } \\
11 \text { February } \\
22 \text { March }\end{array}$ & $\begin{array}{l}18 \\
13 \\
11\end{array}$ & $\begin{array}{l}\text { Not known } \\
\text { Type } 3 \\
\text { Types } 1 \text { and } 2\end{array}$ & $\begin{array}{l}\text { Acute infective encephalitis } \\
\text { Non-paralytic poliomyelitis } \\
\text { Encephalitis }\end{array}$ & $\begin{array}{l}\text { Survey case } \\
\text { Notified case } \\
\text { Gross residual mental and physical } \\
\text { disability }\end{array}$ \\
\hline $\begin{array}{r}4 \\
5 \\
6 \\
7 \\
\end{array}$ & $\begin{array}{l}M \\
M \\
F \\
F\end{array}$ & $\begin{array}{l}5 / 12 \\
7 \\
1 \\
7 / 12\end{array}$ & $\begin{array}{l}\text { Nil } \\
\text { Oral } 1 \\
\text { Nil } \\
\text { Nil }\end{array}$ & $\begin{array}{l}14 \text { June } \\
5 \text { July } \\
7 \text { July } \\
8 \text { September }\end{array}$ & $\begin{array}{r}4 \\
11 \\
1 \\
20\end{array}$ & $\begin{array}{l}\text { Type } 3 \\
\text { Not known } \\
\text { Type } 2 \\
\text { Type } 3\end{array}$ & $\begin{array}{l}\text { Encephalitis } \\
\text { Acute encephalitis } \\
\text { Right facial paresis } \\
\text { Meningo-encephalitis }\end{array}$ & Fatal. Survey case \\
\hline $\begin{array}{l}1904 \\
1 \\
2 \\
3 \\
4 \\
5 \\
6\end{array}$ & $\begin{array}{l}M \\
M \\
F \\
F \\
M \\
M\end{array}$ & $\begin{array}{l}5 \\
12 \\
5 \\
12 \\
5 \\
7 / 12\end{array}$ & $\begin{array}{l}\text { Oral } 3 \\
\text { Nil } \\
\text { Nil } \\
\text { Nil } \\
\text { Injected } 3 \\
\text { Nil }\end{array}$ & $\begin{array}{l}12 \text { February } \\
26 \text { April } \\
1 \text { June } \\
17 \text { June } \\
7 \text { July } \\
11 \text { July }\end{array}$ & $\begin{array}{c}6 \\
20 \\
4 \\
4 \\
21 \\
\text { Not known }\end{array}$ & $\begin{array}{l}\text { Type } 2 \\
\text { Type } 3 \\
\text { Type } 3 \\
\text { Negative } \\
\text { Type 1 } \\
\text { Type } 2\end{array}$ & $\begin{array}{l}\text { Encephalitis } \\
\text { Aseptic meningitis } \\
\text { Meningism } \\
\text { Non-paralytic poliomyelitis } \\
\text { Non-paralytic poliomyelitis } \\
\text { Slight fit and clumsy movement } \\
\text { left arm }\end{array}$ & $\begin{array}{l}\text { Fatal } \\
\text { Notified case } \\
\text { Notified case }\end{array}$ \\
\hline $\begin{array}{l}7 \\
8\end{array}$ & $\begin{array}{l}M \\
M\end{array}$ & $\begin{array}{l}5 \\
8 / 12\end{array}$ & $\begin{array}{l}\mathrm{Nil} \\
\mathrm{Nil}\end{array}$ & $\begin{array}{l}16 \text { October } \\
12 \text { November }\end{array}$ & $\begin{array}{r}8 \\
21\end{array}$ & $\begin{array}{l}\text { Type } 1 \\
\text { Type } 1\end{array}$ & $\begin{array}{l}\text { Convulsions of unknown aetiology } \\
\text { ? Neuritis }\end{array}$ & Transient weakness right leg \\
\hline
\end{tabular}

TABle VIII.-Patients with Neurological Diseases other than Paralytic Poliomyelitis Whose Household Contact Received Oral Vaccine within 60 Days of Onset of Symptoms

\begin{tabular}{|c|c|c|c|c|c|c|c|c|}
\hline \multirow{2}{*}{$\begin{array}{c}\text { Case } \\
\text { No. }\end{array}$} & \multicolumn{2}{|c|}{ Sex and Age } & \multirow{2}{*}{$\begin{array}{c}\begin{array}{c}\text { Previous } \\
\text { Vaccination } \\
\text { History }\end{array} \\
\text { Injected } 4\end{array}$} & \multirow{2}{*}{$\begin{array}{l}\text { Date of Onset } \\
26 \text { July }\end{array}$} & \multirow{2}{*}{$\begin{array}{c}\begin{array}{c}\text { Interval from } \\
\text { Last Dose Oral } \\
\text { Vaccine (days) }\end{array} \\
35\end{array}$} & \multirow{3}{*}{ 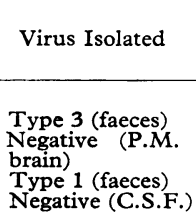 } & \multirow{2}{*}{$\begin{array}{l}\text { Clinical Diagnosis } \\
\text { Acute encephalitis }\end{array}$} & Remarks \\
\hline & $\mathbf{F}$ & 3 & & & & & & $\begin{array}{l}\text { Fatal. P.M. findings consistent with } \\
\text { polioencephalitis }\end{array}$ \\
\hline 1963 & $\mathbf{M}$ & 2 & Injected 3 & 11 November & 22 & & Acute encephalitis & Fatal \\
\hline $\begin{array}{c}1 \\
2 \\
3 \\
4 \\
5 \\
6 \\
7 \\
1964\end{array}$ & $\begin{array}{l}M \\
M \\
M \\
M \\
M \\
F \\
M\end{array}$ & $\begin{array}{l}2 \\
5 \\
2 / 12 \\
26 \\
6 \\
2 \\
12\end{array}$ & $\begin{array}{l}\text { Injected } 3 \\
\text { Injected ? } \\
\text { Nil } \\
\text { Not known } \\
\text { Injected } 1 \\
\text { Nil } \\
\text { Injected } 4\end{array}$ & $\begin{array}{l}17 \text { February } \\
14 \text { March } \\
1 \text { May } \\
1 \text { June } \\
9 \text { June } \\
16 \text { July } \\
19 \text { July }\end{array}$ & $\begin{array}{r}25 \\
45 \\
7 \\
14 \\
45 \\
27 \\
1-2 \text { months }\end{array}$ & $\begin{array}{l}\text { Type 1 } \\
\text { Not known } \\
\text { Type } 2 \\
\text { Type } 2 \\
\text { Not known } \\
\text { Not known } \\
\text { Not known }\end{array}$ & $\begin{array}{l}\text { Meningitis } \\
\text { Acute encephalitis } \\
\text { Meningism } \\
\text { Polyneuritis } \\
\text { Acute infective encephalitis } \\
\text { Post-infective encephalitis } \\
\text { Acute infective encephalitis }\end{array}$ & $\begin{array}{l}\text { Weakness both quadriceps } \\
\text { Survey case } \\
\text { Hydrocephalic infant } \\
\text { Weakness and paraesthesiae of legs } \\
\text { Survey case } \\
\text { Survey case } \\
\text { Survey case }\end{array}$ \\
\hline $\begin{array}{l}1 \\
2 \\
3\end{array}$ & $\begin{array}{l}M \\
\mathbf{M}\end{array}$ & $\begin{array}{l}5 \\
31 \\
2 / 12\end{array}$ & $\begin{array}{l}\text { Not known } \\
\text { Not known } \\
\text { Nil }\end{array}$ & $\begin{array}{l}6 \text { February } \\
3 \text { March } \\
21 \text { September }\end{array}$ & $\begin{array}{r}52 \\
? 28 \\
20\end{array}$ & $\begin{array}{l}\text { Not known } \\
\text { Not known } \\
\text { Type } 2\end{array}$ & $\begin{array}{l}\text { Acute encephalitis } \\
\text { Acute encephalitis } \\
\text { Convulsions }\end{array}$ & $\begin{array}{l}\text { Fatal. Survey case } \\
\text { Fatal. Survey case } \\
\text { Febrile-upper respiratory infection }\end{array}$ \\
\hline
\end{tabular}


weighed against the benefits of vaccination to the large majority of vaccinees and the community as a whole.

The surveillance scheme derived information from several sources, and it is unlikely that many cases of paralytic poliomyelitis occurring in the years under review were not reported in one way or another. Most cases were notified by clinicians to medical officers of health. Only a few additional patients with paralytic poliomyelitis (11\% of the cases in 1963-4) were discovered, most of them by inquiry into reports of the isolation of poliovirus. It is possible that in making a diagnosis of poliomyelitis clinicians were influenced by the patient's vaccination history, but the finding that vaccine-associated cases formed a similar proportion of confirmed cases as of those in which the final diagnosis was not poliomyelitis suggests that vaccineassociated cases were unlikely not to have been reported for this reason.

In judging the safety of oral vaccine it was considered essential to inquire into all types of neurological disease, whether diagnosed as poliomyelitis or not, which could conceivably have been due to the vaccine. Altogether only 38 such cases occurring within 28 days of vaccination of the patient have been recorded, an incidence of about one in every half-million doses given. This may be an underestimate of the true incidence, because cases were collected by systematic inquiries for only part of the time and from a variety of sources, none of which would provide comprehensive records of all cases that might have occurred. Nevertheless, a careful search has not revealed a very large number, and, taking all sources of information together, it seems likely that any substantial incidence of vaccine-associated disease would have been revealed. It is in any case difficult to assess the significance of these cases, for when large numbers of persons are vaccinated some illnesses may be expected by chance alone to be associated chronologically with giving the vaccine. But even if all the incidents recorded were in fact due to the vaccine the frequency of complications compares favourably with, for instance, that following smallpox vaccination (Conybeare, 1964).

For reasons already given, it can reasonably be assumed that most cases of vaccine-associated paralytic poliomyelitis were notified. There were 20 such cases, an incidence of about one case in every million doses given. But only four cases occurring between 5 and 28 days after vaccination had definite residual paralysis. This represents an incidence of one case in every four and a half million doses given. Three of the four occurred in infants, and, although it is not possible to calculate the incidence by age, most of the vaccine was undoubtedly used for primary immunization of infants.

There was no evidence other than the chronological associations with vaccination to suggest that the vaccine caused disease. There was no association of cases with particular batches of vaccine. The proportion of all confirmed paralytic cases which were vaccine-associated in each year changed little despite variations in the amounts of vaccine used. Studies of their vaccination histories and of the age, sex, and seasonal and geographical distribution of cases did not reveal any important or unexpected differences between vaccine-associated and other cases.

No direct comparison can be made with figures from the United States (Henderson et al., 1964), because American practice differed in giving each vaccine virus type separately rather than together as in the United Kingdom. Nevertheless the incidence of vaccine-associated cases with residual paralysis is of the same order as that found in America. The high proportion of vaccine-associated cases among adults in the United States has not been observed, but this may be due to the small number of adults vaccinated in this country. The incidence of vaccine-associated cases was lowest in the U.S. among children aged 5 to 14 years, possibly owing to previous Salk vaccination; the rate in children under 5 years was nearly as high as in adults.
The number of cases in each year with a household contact who had received vaccine within 60 days of onset was consistent with the falling incidence of poliomyelitis in these years rather than with the number of doses of oral vaccine given, which suggests it is improbable that vaccine strains are spreading to cause disease among close contacts of vaccinees. It is not possible to be certain that this may not occur after several passages from one contact to another, but on the present evidence this seems unlikely.

The difficulties of interpreting virus-isolation results when trying to decide whether a case might have been induced by vaccine virus, particularly after the use of trivalent vaccines, have been discussed by Stuart-Harris (1964). Clear distinction between "wild" and vaccine strains by laboratory tests is possible in only a minority of strains, and, in any case, identification of vaccine virus in the faeces would not imply that it necessarily caused the disease. Laboratory identification of vaccine strains was therefore not considered in assessing vaccine safety. However, in view of the American finding that the incidence of paralytic poliomyelitis after type 3 vaccine was much higher than after types 1 and 2 , the more frequent isolation of type 3 virus than of the other types more than five days after vaccination requires attention. But the finding was not unexpected, for several studies have provided evidence that after vaccination with trivalent vaccine type 3 strains are excreted later and for longer periods than types 1 and 2 (Public Health Laboratory Service, 1962 ; Gelfand et al., 1963 ; Galbraith, 1965).

The reason for the change in the frequency of virus isolation from other cases of paralytic poliomyelitis since 1962 is uncertain, but the much lower isolation rates in vaccinated and unvaccinated patients of all ages in the later years suggests that an increased proportion of cases diagnosed as poliomyelitis were not due to infection with poliovirus. The lower proportion of type 1 isolations since 1962 may have been due to the absence of epidemics: types 2 and 3 were relatively more common in non-epidemic years before the introduction of oral vaccine (unpublished data). No such fall in isolation rate occurred in the United States, although there was a similar rise in the proportion of cases from which type 3 virus was isolated.

Finally, in deciding whether the possible risks of Sabin vaccine are acceptable, the risks of the alternative, Salk vaccine, need to be considered. Apart from accidents like the Cutter incident, against which strict precautions are observed, occasional cases of paralytic poliomyelitis, encephalitis, and other neurological disorders have been reported within 28 days of Salk vaccination. The significance of these illnesses after both types of vaccine cannot finally be determined. Nevertheless, when all vaccine-associated cases are considered together it is clear that compared with some other immunizing agents both vaccines are exceptionally safe and any risk appears to be well justified by the benefits conferred. Each vaccine has advantages and disadvantages (Stuart-Harris, 1964), but we are singularly fortunate in possessing a choice between two such outstandingly safe and effective vaccines.

\section{Summary and Conclusions}

The results of the poliomyelitis surveillance scheme in England and Wales for the three years 1962-4, during which live attenuated (Sabin) vaccine was used for routine immunization, are presented. Information was obtained by inquiry into notified cases of poliomyelitis and into other neurological disease associated with administration of the vaccine reported from a variety of sources.

Assessment of the safety of Sabin vaccine has been based on clinical and epidemiological evidence. Thirty-eight cases of neurological disease, including 20 cases of paralytic poliomyelitis, in which the patient had received oral vaccine within 
28 days of onset of symptoms, were reported. Residual paralysis was found in only four cases of paralytic poliomyelitis occurring between 5 and 28 days after vaccination, an incidence of 1 in four and a half million doses administered. Three of the four were infants: there was no evidence, as in the United States, of a higher incidence in adults. No particular vaccine batches were implicated. Studies of the age, sex, and geographical distribution of cases and of their vaccination histories did not reveal any important differences between vaccine-associated and other cases. It is considered unlikely that disease was caused by spread of vaccine virus to contacts of vaccinated persons.

Type 3 poliovirus was isolated proportionately more often from vaccine-associated than from other cases, but this finding was not unexpected after administration of vaccine containing all three virus types. The frequency of isolation of poliovirus from other cases of paralytic poliomyelitis fell between 1962 and 1963-4, suggesting that a greater proportion of cases diagnosed as poliomyelitis in the later years may not have been due to infection with poliovirus.

It is concluded that the risk, if any, of the vaccine causing serious disease was extremely small, and, in view of the benefits conferred by vaccination, it did not justify any change in the present recommendations for the use of oral (Sabin) vaccine.
We are indebted to the many medical officers of health, hospital clinicians, general practitioners, and virologists who have co-operated in providing information concerning their patients, and to the Ministry of Health for the statistics on the use of oral vaccine.

\section{REFERENCES}

Conybeare, E. T. (1964). Mth Bull. Minist. Hlth Lab. Serv., 23, 126, $150,182$.

Galbraith, N. S. (1963). Proceedings of the Ninth Symposium of the European Association Against Poliomyelitis and Allied Diseases, Stockholm.

(1965). F. Hyg. (Lond.). In press.

Geffen, T. J. (1960). Mth. Bull. Minist. Hlth. Lab. Serv., 19, 196.

- and Spicer, C. C. (1960). Lancet, 2, 87.

Gelfand, H. M., Holguin, A. H., Marchetti, G. E., and Feorino, P. M. (1963). Amer. F. Hyg., 78, 358.

Henderson, D. A., Witte, J. J., Morris, L., and Langmuir, A. D. (1964), 7. Amer. med. Ass., 190, 41 .

Nathanson, N., and Langmuir, A. D. (1963). Amer. F. Hyg., 78, 16.

Public Health Laboratory Service (1962). Brit. med. F., 2, 142.

Roden, A. T. (1964). Proc. roy. Soc. Med., 57, 464.

Stuart-Harris, C. H. (1964). Ibid., 57, 459.

Special Advisory Committee to the Surgeon General of the Public Health Service (1964). F. Amer. med. Ass., 190, 49.

Terry, L. L. (1962). The association of cases of poliomyelitis with the use of type 3 oral poliom
Dept. Hith Educ. Welfare.

\title{
Effect of Treatment of Thyrotoxicosis on Exophthalmos
}

\author{
W. R. GREIG, * M.D., M.R.C.P.ED. ; S. A. ABOUL-KHAIR, † M.B., PH.D., D.C.H. ;
}

S. D. MOHAMED $\ddagger$ M.B., M.R.C.P., M.R.C.P.ED. ; J. CROOKS,§ M.D., F.R.C.P.ED., F.R.C.P.GLASG., M.R.C.P.

Brit. med. F., 1965, 2, 509-510

It is known that the treatment of thyrotoxicosis tends to increase the degree of exophthalmos (Werner, Coelho, and Quimby, 1957 ; Werner, 1961 ; Scholz, Haines, and Henderson, 1962 ; Trotter, 1962). Clinical impressions suggest that there may be an inverse relation between the rate of control of symptoms and this increase, but objective evidence for this view is lacking. In the present investigations we have studied the changes in exophthalmos associated with differing rates of control in thyrotoxic patients treated with antithyroid drugs and radioactive iodine.

\section{Material and Methods}

Selection of Patients.-Seventy-two untreated thyrotoxic patients were selected for study. All were investigated in hospital, and the diagnosis was made on clinical grounds (Crooks, Murray, and Wayne, 1959), serum protein-bound iodine (P.B.I.) estimations (Farrell and Richmond, 1961), and radioiodine studies (Macgregor and Wayne, 1958). None suffered from other associated organic disease, and all eventually

\footnotetext{
* Research Fellow, Department of Materia Medica and Therapeutics, University of Aberdeen. Present address : Department of Medicine, Royal Infirmary, Glasgow.

† Research Fellow, Department of Materia Medica and Therapeutics, University of Aberdeen.

¥ Senior Registrar and Clinical Tutor in Medicine, University Department of Materia Medica and Therapeutics and Royal Infirmary, Aberdeen.

$\$$ Reader, Department of Materia Medica and Therapeutics, University of Aberdeen.
}

responded satisfactorily to treatment. Mild-to-moderate exophthalmos was present in each case but none suffered from malignant exophthalmos. Forty-two of the patients were treated with radioiodine. The principles of selection, general management, and method of dose-prescription were similar to those of Macgregor (1957) and of Crooks, Buchanan, Wayne, and Macdonald (1960). Thirty patients were treated with methylthiouracil and received $600 \mathrm{mg}$. daily for the first two weeks of treatment and then $300 \mathrm{mg}$. daily till they were considered to be euthyroid.

Procedure.-Before treatment was started all patients had a standard clinical assessment carried out, the therapeutic index (T.I.) described by Crooks, Wayne, and Robb (1960) being used, and the degree of exophthalmos was measured by means of a Zeiss-Hertel exophthalmometer. After treatment with methylthiouracil was begun or radioactive iodine had been given, each patient was seen at intervals of two weeks, then monthly at an out-patient clinic. At each attendance the clinical response (T.I.), the serum P.B.I., and the exophthalmos were measured. A patient was regarded as euthyroid if the T.I. was five or less and the serum P.B.I. was within the normal range (3.4-7.2 $\mu \mathrm{g} . / 100 \mathrm{ml}$.) at two successive visits.

\section{Results}

The effect that the treatment of thyrotoxicosis has on the degree of exophthalmos is shown in Table I. The mean value of the exophthalmometric measurements (sum of both eyes) in 